\title{
The Relationship Between Instagram Usage \& Body Image of Social Media Influencer Followers: Social Comparison as a Mediator
}

\author{
Novi Hidayati Afana ${ }^{1}$ Niken Widi Astuti ${ }^{1}$ Meylisa Permata Sari ${ }^{1 *}$ \\ ${ }^{1}$ Faculty of Psychology, Universitas Tarumanagara, West Jakarta 11440, Indonesia \\ ${ }^{*}$ Corresponding author. Email: meylisa.sari@fpsi.untar.ac.id
}

\begin{abstract}
This study examined the relationship between intensity of Instagram use and body image concerns. Total of participants 192 early adulthood from Indonesia aged 18-40 years gathered by using snowball sampling and purposive sampling technique. The method that was used in this research is a non-experimental quantitative method. There were three instruments used in this research, there were adapted Facebook Intensity Scale, Physical Appearance Comparison Scale-Revised (PACS-R) has been adapted social media influencer as target, and Multidimensional Body-Self Relations Questionnaire Appearance Scale (MBSRQ-AS) The result showed that social comparison based appearance mediated relationships between Instagram use and variable related to body image concern this means that the research hypothesis is accepted.
\end{abstract}

\section{Keywords: Instagram, social comparison, body image, social media influencer}

\section{INTRODUCTION}

Early adulthood is a stage of development that encourages individuals to socialize more or establish relationships with more people so that individuals pay more attention to their appearance because having an attractive appearance will support individual confidence and become the key to success in social life [1]. But starting in February 2020, social life has changed since a new type of pandemic caused by a virus has mostly spread to the world, this virus is COVID-19 which originated in China and quickly spreads and affects hundreds to millions of people in just a short time [2]. To reduce the spread of this virus, the World Health Organization recommends social distancing and quarantine during the pandemic for all areas that have been affected [3]

According to Saud et al. [4] the same condition occurs in Indonesia, the government is trying to reduce the level of direct public interaction, either by changing state regulations to carry out lockdowns, smart lockdowns, and minimum physical interactions. To reduce direct physical interaction, social media is a significant tool for communicating and continuing routines during the pandemic [5]. A pandemic like this makes residents afraid of being infected, coupled with the imposition of lockdowns and restrictions on physical interaction have encouraged more individuals than ever to use social media networks to stay connected because users feel they have a safe space to continue interacting without the risk of transmission said Synder [6].

Based on a survey, Instagram is included in the 5 most popular or frequently used social media in the world [7].
Instagram is generally known as a social media for sharing photos which was first launched in 2010 and became popular in 2013 [8]. A survey by NapoleonCat [9] stated there are nearly 80 million users of the Instagram social media in Indonesia who are dominated by early adults in August 2020.

According to Bair et al. [10] digital media in the form of social media sites such as Instagram is a popular for providing facilities for appearance-related images. Not only for upload some short photos or videos, but users of this application also can gives comments and likes on posts, exchange messages through direct message features, and follow other user accounts [11]. Follows some social media influencer accounts is one of the activities that could be done through Instagram. Attractive content, desire to follow information the lifestyle of social media influencers, and making social media influencers as motivation and inspiration are some reasons why someone wants to follow a social media influencer account [12]

Due to the large number of followers, several well-known social media influencers are very influential in the real world and social media [13]. So that users selectively upload content according to the self-image that they want to build and show, like their ideal image [14]. And body image distortion is one of the more prominent problems in today's youth, because both men and women become more subjective on social media influencers which can increase body image dissatisfaction [15].

Body image is a picture in someone's mind about their appearance such as the size and shape of body, as well as the attitude a person makes towards the characteristics of the body [16]. According to Aldina [17] disruption or 
distortion of body image will cause dissatisfaction. Dissatisfaction with body image increases between middle and high school, and increases further in early adulthood [18].

Wang et al. [19] say adolescence and early adulthood are different developments, with shifting roles in life and social relationships, different career responsibilities and changes in body shape and weight causing body dissatisfaction to increase with age as men and women enter adulthood. In addition, Brazier [20] said that the media can also affect a person's body image, all of these things can make both men and women even young people believe that the ideal body is real. The phenomenon of social media influencer uploads featuring ideal body figures referring to perfect body shape makes other Instagram users experience dissatisfaction with their bodies [21]. Research conducted by Brown and Tiggerman [22] states that exposure to images of social media influencers with ideal and attractive bodies can damage the body image of the individual.

Active users of social media such as social media influencers who are supported by receiving a large number of comments, replies, and likes in their uploads as a sign of acceptance of their content make them a target for upward social comparisons by other Instagram users [23]. Increased interaction via social media also allows users to make upward social comparisons to personal information [24]. Social comparisons based on appearance comparisons are a part that can affect the formation of body image as the main result of the relationship between social media and a person's body image [25].

This information allows other users who see themselves to be not good enough and make poor self-evaluations [26]. Body image problems arise between what an individual's body really is and the projections of what the body should be. Social media, especially Instagram, causes excess information about a body that looks perfect and creates negative comparisons and self-perceptions [27].

Based on the various descriptions of the information above, the researcher hereby have an interest in research on whether social comparison becomes a mediator variable between the relationship between intensity of Instagram use and body image of early adulthood who follows social media influencer accounts.

\subsection{Related Work}

\subsubsection{Early adulthood}

According to Papalia et al. [28] development of adulthood is divided into three parts, first stage is early/young adulthood with ages ranging from 20 to 40 years, middle adulthoods with ages ranging from 40 to 65 years, and the last one is late adulthood with ages from 65 years and over. Papalia and Martorell [29] based on the theory put forward by Shaei explained that young adults are individuals aged from early 20 to early 30 years, at this age it is called achieving stage which is defined as a early adult acquiring knowledge not only for themselves but also for use to achieve goals, such as career and family.

\subsubsection{Body image}

According to Rudd and Lennon [30] body image is an individual's mental image of body which consists of a perceptual component which refers to how the individual perceives the size, shape, weight, and performance of the body, as well as the attitude component which refers to how individual feelings about these attributes and lead to a behavior. Body image is assessed by measuring individual satisfaction or dissatisfaction based on body shape in terms of subjective importance [31].

Body image refers to a person's emotional attitudes, beliefs, and perceptions so that the results of the image of a person's body are divided into two, there are positive or negative body image [32]. Body image has 2 main dimensions, Appearance Evaluation and Appearance Orientation, and 3 additional dimensions, Body Area Satisfaction, Overweight Preoccupation, and Self-Classified Weight [33].

Appearance Evaluation is a measure of performance evaluation that is categorized as being satisfied or dissatisfied with a person's body image [34]. Appearance Orientation, dimension of the level of a person's value on their appearance, high assessment results in body image have an important role so that someone pays attention to and takes care of appearance, while low assessment results consider it not very important and do not spend a lot of effort to look good [35].

The next dimension is Body Area Satisfaction, is defined as satisfaction with body parts by measuring individual satisfaction with that particular body part [36]. Overweight Preoccupation is a dimension of individual anxiety about their body shape which has the possibility of becoming obese, this awareness has an impact on the individual's desire to have a strict diet and limit eating patterns [37]. The last dimension of Self-Classified Weight is the individual's perception and assessment of their weight starting from underweight to being overweight which occurs as a result of the individual's own views and according to others [38].

\subsubsection{Instagram}

Instagram is a social media developed by Kevin Systrom and Mike Krieger in San Francisco, California which was first officially launched on October 6, 2010 [39]. This social media is a free photo sharing application that popular in providing communication effectiveness and as a marketing tool for displaying products in a visual way [40]. Rousseau and Foulk [41] state that Instagram is a social media application that allows users to share photos and videos, add descriptions, edit with filters, and stay in touch with other people.

\subsubsection{Social media influencer}

Social media influencers represent a new type of third-party supporter who independently shapes audience attitudes through blogs, tweets, or the use of social media [42]. According to Newberry [43] a social media influencer is someone who has influence through social media. The right 
influencer can reach the target audience, build trust, and encourage a relationship engagement with followers on social networking media. To attract the engagement of their followers, influencers create original and engaging content. Influencers differ from celebrities in that influencers thrive through social networking media and build reputation among followers through the actions taken in these media. On the other hand, the fame enjoyed by celebrities often comes from activities outside of social media, such as television, music, magazines, and other media. As a result, influencers can develop closer relationships with followers, which leads to the formation of credible and trustworthy relationships [44].

\subsubsection{Social comparison}

Social media influencers represent a new type of third-party supporter who independently shapes audience attitudes through blogs, tweets, or the use of social media (Freberg et al., 2011). According to Newberry (2019) a social media influencer is someone who has influence through social media. The right influencer can reach the target audience, build trust, and encourage a relationship engagement with followers on social networking media. To attract the engagement of their followers, influencers create original and engaging content.

Influencers differ from celebrities in that influencers thrive through social networking media and build reputation among followers through the actions taken in these media. On the other hand, the fame enjoyed by celebrities often comes from activities outside of social media, such as television, music, magazines, and other media. As a result, influencers can develop closer relationships with followers, which leads to the formation of credible and trustworthy relationships [42].

\subsection{Paper Structure}

The first section discussed this study background. Section 2 describes research participants, instrument used to measure, and explain our data analysis plan. Section 3 presents analysis result and its interpretation followed by discussed. In section 4, we will conclude current study and discussed limitation of this study and direction for future research.

\section{METHODS}

\subsection{Participants}

The research method used in this research is nonexperimental quantitative research methods. The sampling technique in this study is non-probability sampling. The type of sampling used in this study is snowball sampling. In addition to using snowball sampling, the sampling in this study also used purposive sampling as a support in sampling so that it is more identified according to the required characteristics of the participants.
Participants who took part in this study were 192 participants aged 18-40 years who had personal Instagram accounts, had used Instagram regularly for a month before filling out the research questionnaire, and followed influencers' social media accounts that were verified by Instagram.

\subsection{Instruments}

\subsubsection{Facebook intensity scale}

The Facebook Intensity Scale instrument was developed by Ellison et al. (2007). This instrument has a focus on how much time is spent on Facebook. The scale used in the Facebook Intensity Scale measuring instrument that has been adapted to measure the intensity of Instagram use is the 5-point Likert Scale. This instrument consists of 8 items $(\alpha=0.838)$ that indicate how long the intensity of the use of the Facebook social media media is, but for this study it will be adapted to the intensity of the use of the Instagram social network media which is associated with a focus on following influencer social media accounts.

\subsubsection{Physical appearance comparison-R scale}

The Physical Appearance Comparison Scale (PACS) is a measuring instrument developed by Thompson et al. (1991) which was later revised by Schaifer and Thompson (2014) to become the Physical Appearance Comparison-Revised Scale (PACS-R) $(\alpha=0.952)$. This measuring tool was developed to measure the level of social performance comparison. The scale used in the PACR-S measuring instrument which has been adapted to measure social performance comparisons is the 5-point Likert Scale.

PACS-R is a measuring instrument with 11 statement items that indicate the assessment tendency in 8 social contexts and with 5 different aspects of a person's physical appearance. However, because there are several statement items measuring the same 5 aspects with different social contexts, this study only uses 5 statement items so there are no multiple statements. The items ask participants to indicate how high the frequency of participants is in each type of comparison. However, for this study, there will be some adaptations in each item that are associated with a focus on comparisons with yourself and the influencers' social media accounts that are followed on the social network Instagram.

\subsubsection{Multidimensional body-self relations questionnaire appearance scale}

The MBSRQ-AS is a measuring instrument developed by Thomas F. Cash which is shorter than the MBSRQ as a whole because items on health and fitness are omitted and only focuses on dimensions related to appearance (Cash, 2000). The scale used in the MBSRQ-AS measuring instrument is a 5-point Likert. 
Body image has 2 main dimensions, namely Appearance Evaluation and Appearance Orientation, with 3 additional dimensions of Body Area Satisfaction, Overweight Preoccupation, and Self-Classified Weight (Kusuma \& Krianto, 2018). After being adapted by the Research and Measurement Agency for the Faculty of Psychology at Tarumanagara University, this measuring instrument consists of 34 items measuring 5 dimensions with the following details, (a) 8 items measuring the dimensions of Appearance Evaluation $(\alpha=0.818)$, (b) 12 items measuring the dimensions of Appearance Orientation $(\alpha=0.802)$, (c) 9 items to measure the dimensions of the Body Areas Satisfaction Scale $(\alpha=0.856)$, (d) 3 items to measure the Overweight Preoccupation dimension ( $\alpha=0.927)$, and (e) 2 items to measure the dimensions of the Self Classified Weight $(\alpha=0.697)$

\section{FINDINGS AND DISCUSSION}

The mediation analysis test conducted by the researcher used SPSS 26.00 with the help of Andrew F. Hayes' PROCESS. This test aims to determine whether the trend in making comparisons to influencers' social media accounts can be a mediating variable between the relationship between the dimensions of intensity of use of Instagram and each dimension of early adult body image.

If the test results indicate a significance value of less than 0.05 ( $\mathrm{p}<0.05$ ), it can be interpreted that the hypothesis is accepted and it means that social comparison becomes the mediator variable for the relationship between intensity of Instagram use and early adult body image following social media influencer accounts, conversely if the significance value is more from 0.05 ( $>$ > 0.05) the hypothesis is rejected, which means that social comparison does not become a mediator variable between the two variables.

\subsection{Appearance evaluation}

In the dimension of Appearance Evaluation, the results of the study show that the intensity of Instagram use is a significant predictor of social comparison, $b=0.2791, \mathrm{SE}=$ $0.632, p=0.000(p<0.05)$, and social comparison is a significant predictor of Appearance Evaluation. $\mathrm{b}=$ $0.2572, \mathrm{SE}=0.0719, \mathrm{p}=0.0004(\mathrm{p}<0.05)$. Intensity of using Instagram is no longer a predictor of Appearance Evaluation after controlling for mediators, namely social comparison, $b=0.0180, \mathrm{SE}=0.0657, \mathrm{p}=0.7843(\mathrm{p}>0.05)$. About $6.7 \%$ of the variance in intensity of Instagram use was explained by predictors $(\mathrm{R} 2=0.0668)$. The indirect effect was tested using the bootstrap estimation approach with 5000 samples. These results indicate that the indirect effect is significant, $\mathrm{b}=0.0286, \mathrm{SE}=-0.0718,95 \% \mathrm{CI}=$ $0.1332,-0.0217$. Thus, there is a significant negative correlation between the intensity of Instagram use and the dimension of Appearance Evaluation is mediated by social comparison (Figure 1).

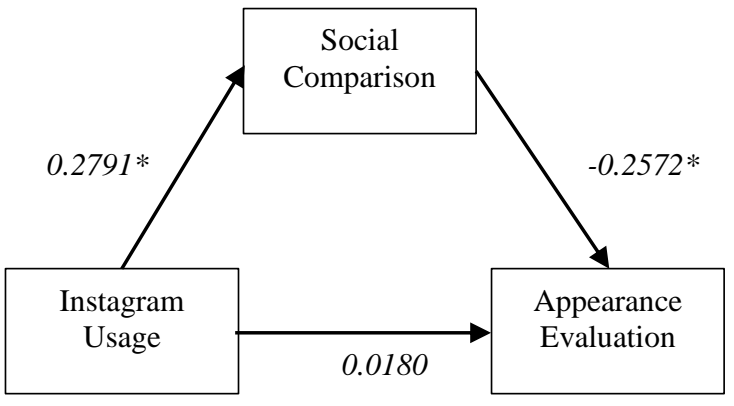

Figure 1 Relationship between intensity of instagram usage with appearance evaluation dimensions mediated by social comparison to social media influencer

\subsection{Appearance orientation}

While the Appearance Orientation dimension, the results showed that the intensity of using Instagram was a significant predictor of social comparison, $b=0.2791, \mathrm{SE}=$ $0.632, p=0.000(p<0.05)$, and social comparison was an insignificant predictor of Appearance Orientation, $\mathrm{b}=$ $01394, \mathrm{SE}=0.0860, p=0.1066(\mathrm{p}>0.05)$. So that the intensity of using Instagram becomes a predictor of body image dimensions after controlling for the mediator, namely social comparison, $\mathrm{b}=0.2074, \mathrm{SE}=0.0786, \mathrm{p}=0.0090(\mathrm{p}$ $<0.05)$. Approximately $6.6 \%$ of the variance in intensity of Instagram use was explained by predictors $(\mathrm{R} 2=0.0664)$. The direct effect was tested using a bootstrap estimation approach with 5000 samples. These results indicate that the direct effect is significant, $\mathrm{b}=0.0786, \mathrm{SE}=0.2074,95 \% \mathrm{CI}$ $=0.0523,0.3625$. Thus, there is a significant positive correlation between the intensity of Instagram use and the Appearance Orientation dimension without being mediated by social comparisons (Figure 2).

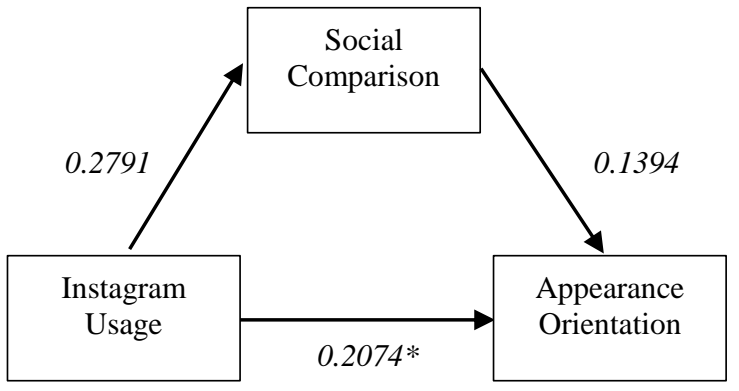

Figure 2 Relationship between intensity of instagram usage with appearance orientation dimensions mediated by social comparison to social media influencer

\subsection{Body areas satisfaction}

The results of the research on the dimensions of Body Areas Satisfaction show that the intensity of Instagram use is a significant predictor of social comparison, $b=0.2791, \mathrm{SE}=$ $0.632, p=0.000(p<0.05)$, and social comparison is a significant predictor of Body Areas Satisfaction, $b=$ $0.2682, \mathrm{SE}=0.0832, \mathrm{p} 0.0015(\mathrm{p}<0.05)$. Intensity of using 
Instagram is no longer a predictor of body image dimensions after controlling for the mediator, namely social comparison, $\mathrm{b}=-0.0386, \mathrm{SE}=0.0760, \mathrm{p}=0.6126(\mathrm{p}>0.05)$. About $6.4 \%$ of the variance in intensity of Instagram use was explained by predictors $(\mathrm{R} 2=0.0637)$. The indirect effect was tested using the bootstrap estimation approach with 5000 samples. These results indicate that the indirect effect is significant, $b=0.0293, \mathrm{SE}=-0.0748,95 \% \mathrm{CI}=$ $0.1384,-0.0236$. Thus, there is a significant negative correlation between the intensity of Instagram use and the dimensions of body image Body Areas Satisfaction mediated by social comparisons (Figure 3 ).

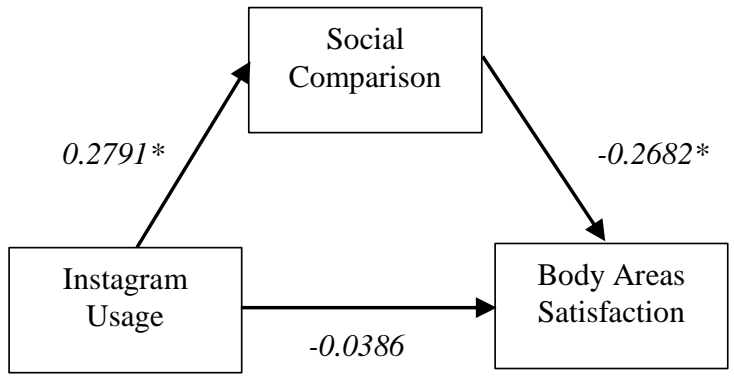

Figure 3 Relationship between intensity of instagram usage with body areas satisfaction dimensions mediated by social comparison to social media influencer

\subsection{Self-classified weight}

For the dimensions of Self Classified Weight, the results showed that the intensity of Instagram use was a significant predictor of social comparison, $\mathrm{b}=0.2791, \mathrm{SE}=0.632, \mathrm{p}=$ 0.000 ( $\mathrm{p}<0.050$ ), and social comparison was a significant predictor of body image dimensions. Classified Weight, $\mathrm{b}=$ $0.0655, \mathrm{SE}=0.0255, \mathrm{p}=0.0111(\mathrm{p}<0.05)$. Intensity of using Instagram is no longer a predictor of Self Classified Weight after controlling for the mediator, namely social comparison, $b=-0.0215, \mathrm{SE}=0.0233, \mathrm{p}=0.3575(\mathrm{p}>0.05)$. About $3.4 \%$ of the variance in intensity of Instagram use was explained by predictors $(\mathrm{R} 2=0.0338)$. The indirect effect was tested using the bootstrap estimation approach with 5000 samples. These results indicate that the indirect effect is significant, $\mathrm{b}=0.0083, \mathrm{SE}=0.0183,95 \% \mathrm{CI}=$ $0.0038,0.0364$. Thus, there is a significant negative correlation between the intensity of Instagram use and the dimensions of body image Self-Classified Weight mediated by social comparisons (Figure 4).

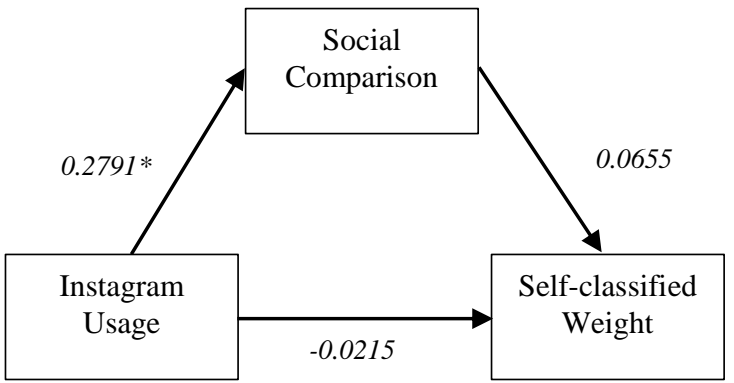

Figure 4 Relationship between intensity of instagram usage with self-classified weight dimensions mediated by social comparison to social media influencer

\subsection{Overweight preoccupation}

And for the last body image dimension, the Overweight Preoccupation dimension, has research results which show that the intensity of Instagram use is a significant predictor of social comparison, $b=0.2791, \mathrm{SE}=0.632, \mathrm{p}=0.000(\mathrm{p}$ $<0.05$ ), and social comparison is a predictor significant from the dimensions of body image Overweight Preoccupation, $\mathrm{b}=0.2342, \mathrm{SE}=0.0364, \mathrm{p}=0.000(\mathrm{p}$ $<0.05)$. Intensity of using Instagram was no longer a predictor of body image dimensions after controlling for the mediator, namely social comparison, $\mathrm{b}=0.0511, \mathrm{SE}=$ $0.7041, p=0.1261(p>0.05)$. About $22.55 \%$ of the variance in intensity of Instagram use was explained by predictors $(\mathrm{R} 2=0.2255)$. The indirect effect was tested using the bootstrap estimation approach with 5000 samples. These results indicate that the indirect effect is significant, $\mathrm{b}=$ $0.0173, \mathrm{SE}=0.0654,95 \% \mathrm{CI}=0.0345,0.1016$. Thus, there is a significant negative correlation between the intensity of Instagram use and the dimensions of body image. Overweight Preoccupation is mediated by social comparison (Figure 5).

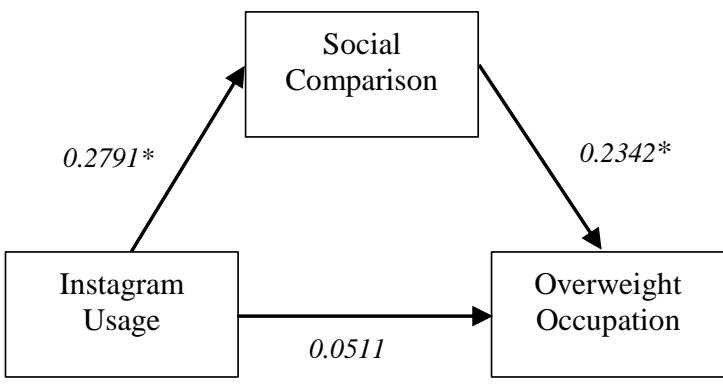

Figure 5 Relationship between intensity of instagram usage with overweight preoccupation dimensions mediated by social comparison.

\section{CONCLUSION}

Based on the results of the above research, it is concluded that there is a positive and significant relationship between the intensity of Instagram use and body image with the tendency to make comparisons to the influencer social media accounts as the mediator variable. In addition, based 
on the mediation test conducted, only the Appearance Orientation dimension does not need to go through the mediator variable to be able to determine the direct relationship between the intensity of Instagram use and body image. For other dimensions such as Appearance Evaluation, Body Areas Satisfaction Scale, and Self Classified Weight, the results show that the mediator variable is needed to see how the relationship between intensity of Instagram use and body image is related.

\section{ACKNOWLEDGMENT}

This work was supported by Faculty of Psychology, Universitas Tarumanagara, West Jakarta, Indonesia. Researchers also showing gratitude for each participant who has been willing to participates in this study.

\section{REFERENCES}

[1] Khotamanisah. Persepsi terhdap citra tubuh ideal dengan body dissatisfaction pada wanita dewasa awal. 2017, [Unpublished thesis]. Universitas Negeri Malang.

[2] L. Duan, G. Zhu. Psychological interventions for people affected by the COVID-19 epidemic, The Lancet Psychiatry. 7(4) (2020) 300-302.

[3] J. L. Wang, H. Z. Wang, H. Z. Gaskin, J. S. Hawk, The mediating roles of upward social comparison and selfesteem and the moderating role of social comparison orientation in the association between social networking site usage and subjective well-being, Frontiers in Psychology, (2017) https://www.frontiersin.org/articles/10.3389/fpsyg. 2017.00771/full

[4] M. Saud, R. Ida, M. Mashud. Democratic practices and youth in political participation: A doctoral study, International, Journal of Adolescence and Youth. 25 (2020) 800-808. DOI: 10.1080/02673843. 2020.1746676

[5] N. A. Al Eid, B. A. Arnout, Crisis and disaster management in the light of the Islamic approach: COVID19 pandemic crisis as a model (a qualitative study using the grounded theory), Journal of Public Affairs, (2020) 1-14.

[6] V. Snyder, Social media usage is both increasing and changing in the COVID-19 era: Here are some lessons and new best practices to embrace the trends. Bussiness.com. (2020, Agustus 11).

[7] M, Ikhsan, Survei: 5 media sosial paling popular di dunia. CNN (2020). https://www.cnnindonesia.com/ teknologi/20200819154002-185-537377/survei-5-mediasosial-paling-populer-di-dunia
[8] H. Ting, W. W. P. Ming, E. C. D. Run, S. L. Y. Choo, Beliefs about the use of Instagram: An exploratory study, International Journal of Business and Innovation, 2(2) (2015) 17-19.

[9] NapoleonCat, Instagram users in Indonesia. NapoleonCat. (2020, Agustus). https://napoleoncat.com/ stats/instagram-users-in-indonesia/2020/08

[10] C. E. Bair, N. R. Kelly, K. L. Serdar, S. E. Mazzeo, Does the internet function like magazines? An exploration of image-focused media, eating pathology, and body dissatisfaction, Eating Behaviors, 21(5) (2012) 398-399. DOI: $10.1016 /$ j.eatbeh.2012.06.003

[11] C. Rousseau, T. Foulk, Instagram: Everything you need to know, iMore, (2018, Agustus 14). https:// www.imore.com/instagram

[12] P. Killoren, Why do we follow influencers? Medium (2016, November 7). https://medium.com/admass/why-dowe-follow-influencers-41add76fec 33

[13] R. Liu., \& A. Suh, Self-Branding on social media: An analysis of style bloggers on Instagram. Procedia Computer Science, 124(2017) (2017) 12-13.

[14] E. A. Vogel, J. P. Rosen, L. R. Roberts, K. Eckles, Social comparison, social media, and self-esteem. Psychology of Popular Media Culture, 3(4) (2014) 207-207. DOI: $10.1037 / \mathrm{ppm} 0000047$

[15] J. Aziz. Social media and body issues in young adults: an empirical study on the influence of Instagram use on body image and fatphobia in catalan university students [Skripsi yang tidak dipublikasikan]. Universitat Pompeu Fabra.

[16] H. Sa'diyah, (2015). Pengaruh citra tubuh terhadap penyesuaian diri siswa-siswi kelas VII-VIII SMP NU Syamsuddin Malang [Thesis yang tidak dipublikasikan]. Universitas Islam Negeri Maulana Malik Ibrahim.

[17] A. Aldina, (2020). Tanda terjadinya gangguan citra tubuh (body image) plus cara menerapkan body positivy. HelloSehat. https://hellosehat.com/parenting/remaja/gejala -penyimpangan-citra-tubuh/\#gref

[18] M. M. Bucchianeri, A, J. Arikian, P. J. Hannan, M. E. Eisenberg, D. Neumar-Sztainer, (2013). Body dissatisfaction from adolescence to young adulthood: Findings from a 10-year longitudinal study. Body Image, 10(1), 1-7. DOI: 10.1016/j.bodyim.2012.09.001

[19] S. B. Wang, A. F. Haynos, M. Wall, M. C. Chen, M. E. Eisenberg, \& D. Neumar-Sztainer, (2019). Fifteen-year prevalence, trajectories, and predictors of body dissatisfaction from adolescence to middle adulthood. Clinical Psychological Science, 1-13. DOI: 10.1177/ 2167702619859331 
[20] Y. Brazier, (2017). What is body image? MedicalNewsToday. https://www.medicalnewstoday.com/ articles/249190\#1

[21] E. K. Aristantya, \& A. F. Helmi, (2019). Citra tubuh pada remaja pengguna Instagram. E-journal Gamajop, 5(2),114-116. DOI: 10.22146/gamajop.50624

[22] Z. Brown, \& M. Tiggermann, (2016). Attractive celebrity and peer images on Instagram: Effect on women's mood and body image. Body Image, 19, 37-43. DOI: 10.1016/j.bodyim.2016.08.007

[23] E. A. Vogel, J. P. Rosen, L. R. Roberts, \& K. Eckles, (2014). Social comparison, social media, and self-esteem. Psychology of Popular Media Culture, 3(4), 207-207. DOI: 10.1037/ppm0000047

[24] H. S. Hwang, (2019). Why social comparison on instagram matters: Its impact on depression. KSSI Transactions on Internet and Information Systems, 13(3). 1627-1628. DOI: 0.3837/tiis.2019.03.029

[25] J. Fardouly, R. T. Pinkus, \& L. R. Vartanian, (2017). The impact of appearance comparisons made through social media, traditional media, and in person in women's everyday lives. Body Image, 20(2017), 31-39. DOI: 10.1016/j.bodyim.2014.10.004

[26] J. L. Wang, H. Z. Wang, J. Gaskin, \& S. Hawk, (2017). The mediating roles of upward social comparison and selfesteem and the moderating role of social comparison orientation in the association between social networking site usage and subjective well-being, Frontiers in Psychology (2017). https://www.frontiersin.org/articles/10.3389/fpsyg. 2017.00771/full

[27] Ricky. Instagram's influence on negative body image. Mind That Ego. (2018). https://www.mindthatego.com/ instagram-influence-body-image-part-1/

[28] D. E. Papalia, G. Martorell, Experience human development (13rd ed), 2015, McGraw Hill Education.

[29] D. E. Papalia, S.W. Olds, R.D. Feldman, Human development (9th ed), 2008, Kencana.

[30] N. A. Rudd, S.J. Lennon, Body image and appearancemanagement behaviors in college women. Clothing and Textile Research Journal, 18(3) (2000) 152-162. DOI: 10.1177/0887302X0001800304

[31] T. S Giovannelli, T.F. Cash, J.M. Henson, K. Engle. The measurement of body-image dissatisfactionsatisfaction: Is rating importance important? Body Image, 5(2) (2008) 216-223. DOI: 10.1016/j.bodyim.2008.01.001
[32] T. J. Legg. What is body image? MedicalNewsToday. (2017, April 4). https://www.medicalnewstoday.com/ articles/249190

[33] M. R. H. Kusuma, T. Krianto, Pengaruh citra tubuh, perilaku makan, dan aktivitas fisik terhadap indeks massa tubuh (IMT) pada remaja: Studi kasus pada SMA Negeri 12 DKI Jakarta. Perilaku dan Promosi Kesehatan, 1(1) (2018) 23-31.

[34] J. Dixon, M.E. Dixon, P.E. O’Brien, Body image: Appearance orientation and evaluation in the severely obese. Changes with weight loss. Obesity Surgery, 12 (2002) 65-71. DOI: 10.1381/096089202321144612

[35] J. L. Foland, Body image and body valuation in female participants of an outdoor education program, 2009, [Unpublished Thesis]. University of New York College at Cortland.

[36] T. F. Cash, Body image: A handbook of theory, research, and clinical practice, 2002, Guilford Publications

[37] J. L. Foland, Body image and body valuation in female participants of an outdoor education program, 2009, [Unpublished Thesis], University of New York College at Cortland.

[38] T. F. Cash, Body image: A handbook of theory, research, and clinical practice, 2002, Guilford Publications.

[39] I, Amaral, 2015The SAGE encyclopedia of economics and society: Instagram. Sage Publications, Inc.

[40] H. Ting, W.W.P. Ming, E.C.D. Run, S.L.Y. Choo, Beliefs about the use of Instagram: An exploratory study. International Journal of Business and Innovation, 2(2) (2015) 17-19.

[41] M. Rouse, (2017, Mei). Instagram. SearchCIO https://searchcio.techtarget.com/definition/Instagram

[42] K. Freberg, K, Graham, McGaughey, L. A. Freberg, Who are the social media influencers? A study of public perceptions of personality. Public Relations Review, 37(1) (2011) 90-92. DOI: 10.1016/j.pubrev.2010.11.001

[43] C. Newberry, Influencer marketing guide: How to work with social media influencer. (2019, Mei 2). HootSuite. https://blog.hootsuite.com/influencer-marketing

[44] D. Belanche, M. Flavian, S. Ibanez-Sanchez, Follower's reaction to influencer's Instagram posts. Spanish Journal of Marketing, 24(1) (2002) 37-53. DOI: 10.1108/SJME-11-2019-0100 